\title{
Reformulasi Kebijakan Pengaturan Pelintas Batas Antara Indonesia-Philipina
}

(Riset untuk Rekomendasi Pengaturan ulang Border Crossing Agreement Antara Kedua Negara)

\author{
$1^{\text {st }}$ Joyce Jacinta Rares \\ UNSRAT \\ Fakultas Ilmu Sosial dan Politik \\ Manado, Indonesia \\ $2^{\text {nd }}$ Salmin Dengo \\ FIS UNIMA \\ Prodi Administrasi Negara \\ Tondano, Indonesia \\ $3^{\text {rd }}$ Novva Plangiten \\ FIS UNIMA \\ Prodi Administrasi Negara \\ Tondano, Indonesia
}

\begin{abstract}
Abstrak - Kesepakatan Indonesia - Philipina soal hubungan lintas batas (Border Crossing Agreement) telah berjalan lebih 30 (tiga puluh) tahun. Hasil penelitian sebelumnya (Mamentu dan Rares, 2017) memperlihatkan bahwa kesepakatan Indonesia - Philipina soal perbatasan (Border Crossing Agreement) telah bias dari apa yang tertuang di dalamnya. Border Crossing Agreement
\end{abstract} $(B C A)$ mengatur 3 hal yaitu hubungan kekeluargaan, kegiatan keagamaan dan pleasure. Kenyataannya hubungan lintas batas antara dua penduduk di perbatasan telah berkembang pada hubungan perdagangan, sampai pada kegiatan penangkapan ikan secara bersama-sama yang mekanismenya belum diatur dalam sistem perundang-undangan. Penelitan sebelumnya juga memperlihatkan bahwa dalam kondisi yang seperti ini dan oleh karena kebijakan di dalam negeri yang berbeda, maka keuntungan adalah lebih besar dinikmati oleh pihak Philipina, oleh karenanya menjadi sangat urgen untuk segera meng-update kesepakatan perbatasan antara dua negara, serta merumuskan kebijakan terkait dengan pengelolaan wilayah perbatasan, yaitu Kabupaten Kepulauan Talaud. Penelitian ini berupaya untuk menghasilkan formulasi kebijakan konkrit soal pengaturan hubungan lintas batas antara masyarakat Kabupaten Kepulauan Talaud dan Philipina Selatan, agar supaya keuntungan dari hubungan lintas batas ini menjadi berimbang. Hasil penelitian ini diharapkan dapat menjadi isi dari regulasi formal yang mengatur hubungan penduduk antara dua wilayah ini.

Kata Kunci : Border Crossing Agreement, bias kesepakatan, update kebijakan

\section{PENDAHULUAN}

Hubungan Lintas antara penduduk perbatasan Indonesia (kabupaten Kepulauan Sangihe dan kabupaten kepulauan Talaud) dan Philipina Selatan telah berjalan puluhan tahun. Hubungan ini terkonsentrasi pada dua wilayah, di kabupaten Kepulauan Talaud konsentrasi hubungan terfokus di pulau Miangas dan desa Bowombaru pulau Kabaruan. Sementara khusus di kabupaten Sangihe, hubungan lintas batas antara dua penduduk dari dua wilayah terfokus di kecamatan Marore, dan sebagian (secara sembunyisembunyi) di Desa Peta. Adapun penduduk Philipina Selatan adalah yang berasal dari wilayah-wilayah Davao, Balut Island, Cape San Agustin, Sarangani Island, dan daerah kepulauan Tawi-Tawi.

Kesepakatan pengaturan lintas batas antar dua negara ditandatangi di Jakarta pada tahun 1975 dengan nama JOINT IMPLEMENTATION OF THE BORDER PATROL AGREEMENT AND BORDER CROSSING AGREEMENT BETWEEN THE GOVERNMENT OF THE REPUBLIC OF INDONESIA AND THE GOVERNMENT OF THE REPUBLIC OF THE PHILIPPINES. 
Border Crossing Agreement yang di dalamnya mengatur 3 hal yaitu :
a. Visit of Relatives (kunjungan kekeluargaan).
b. Religoius trip (kunjungan keagamaan).
c. Pleasure.

Kenyataannya, hubungan lintas batas antar penduduk yang di wilayah tersebut sudah jauh "keluar" dari hal-hal yang diatur di dalam Border Crossing Agreement. Persoalannya adalah hal ini berdampak secara signifikan terhadap perekonomian wilayah perbatasan. Hasil dari penelitian-penelitian sebelumnya (Mamentu 2016, Mamentu dan Rares 2017, Mamuaja, 2017), memperlihatkan bahwa hubungan lintas batas sudah menjadi hubungan perdagangan lintas batas. Adapun hal-hal yang teridentifikasi adalah sebagai berikut :

a. Penduduk Philipina Selatan banyak membawa berbagai barang dan dijual di wilayah Indonesia (konsentrasi di pulau Marore).

b. Joint illegal fishing antara penduduk dua wilayah.

c. Masuknya minuman keras dari Philipine secara ilegal di Marore, Peta dan Tahuna.

Kondisi ini memperlihatkan bahwa perlu dilakukan update terhadap Border Crossing Agreement antara dua negara. Atas dasar ini maka perlu dilakukan penelitian lebih mendalam untuk mendapatkan data-data yang lebih mendalam terkait dengan ini hal ini.

Oleh karenanya, maka atas dasar persoalan di atas maka penelitian berupaya untuk menjawab pertanyaan (rumusan masalah) sebagai berikut : "bagaimanakah seharusnya pengaturan hubungan lintas batas antara penduduk perbatasan Indonesia dan Philipina di dalam Border Crossing Agreement antara dua negara ?".

Selanjutnya penelitian ini bertujuan untuk menghasilkan rekomendasi kebijakan yang akan disampaikan kepada lembaga terkait (Kementerian Luar Negeri RI, Kementerian Pertahanan Keamanan RI, Kementerian Kelautan dan Perikanan RI. Kementerian Hukum dan HAM

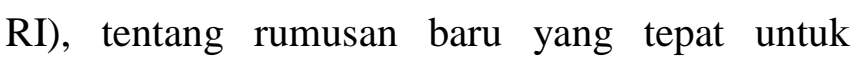

dimuat dalam Border Crossing Agreement antara Indonesia dan Philipina. Adapun manfaat yang diharapkan dapat diperoleh dari penelitian ini adalah dapat memberikan penguatan terhadap perkembangan konseo dan teori-teori kebijakan, terutama sekali terkait dengan formulasi kebijakan, serta dapat menjadi rujukan bagi perbaikan dan penguatan content dari Border Crossing Agreement antara Indonesia dengan Philipina.

\section{TINJAUAN PUSTAKA}

Border Crossing Agreement antara Indonesia dan Philipina pada prinsipnya adalah sebuah keputusan negara untuk kepentingan pulbik dua negara. Oleh karenanya BCA dapat dikategorikan sebagai sebuah policy (kebijakan) yang sifatnya berlaku untuk dua negara. Dalam kaitannya dengan hal ini, maka proses pembuatannya adalah juga masuk dalam kaedah-kadeah formulasi kebijakan publik. Formulasi kebijakan publik merupakan salah satu tahap dari rangkaian proses pembuatan dan pelaksanaan suatu kebijakan publik. Tentang hal ini Dunn (2000:132) menjelaskan bahwa perumusan kebijakan (policy formulation) adalah pengembangan dan sintesis terhadap alternatif-alternatif pemecahan masalah. Sementara Winarno (2002:29) menyatakan bahwa masing-masing alternatif bersaing untuk di pilih sebagai kebijakan dalam rangka untuk memecahkan masalah. Dalam kaitannya dengan konsep ini selanjutnya Tjokroamidjojo dalam Islamy (2000:24) menyebutkan perumusan kebijakan sebagai alternatif yang terus menerus dilakukan dan tidak pernah selesai, dalam memahami proses perumusan kebijakan kita perlu memahami aktor-aktor yang terlibat dalam proses perumusan kebijakan.

Dari berbagai uraian di atas maka dapat dikemukakan bahwa formulasi kebijakan merupakan cara untuk memecahkan suatu masalah yang di bentuk oleh para aktor pembuat kebijakan dalam menyelesaikan masalah yang ada 
dan dari sekian banyak alternatif pemecahan yang ada maka dipilih alternatif kebijakan yang terbaik.

Pada dasarnya kegiatan utama dari formulasi kebijakan adalah memilih alternatif-alternatif guna menangani masalah kebijakan. Penjelelasanpenjelasan alternatif adalah merupakan modelmodel pembuatan keputusan. Winarno (2016: 91113) mengemukakan bahwa terdapat 6 (enam) model formulasi kebijakan yaitu :

a. Model Sistem

Model sistem ditawarkan oleh Paines dan Naumes dalam Winarno $(2016,91)$. Model ini merupakan model deskriptif. Karena lebih berusaha untuk menggambarkan senyatanya hal terjadi dalam pembuatan kebijakan. Model ii disusun dari sudut pandang pembuat kebijakan. Para pembuat kebijakan dilihat perannya dalam perencanaan dan pengkoordinasian untuk menemukan pemecah masalah. Ada tiga hal yang dilakukan yaitu 1) menghitung kesempatan dan meraih atau menggunakan dukungan imtermal dan eksternal. 2) merumuskan permintaan lingkungan, dan 3) secara khusus memuaskan keinginan atau kepentingan para pebuat kebijakan itu sendiri.

b. Model Rasional Komprehensif.

Model ini adalah model yang paling populer. Kebijakan yang rasional jika kebijakan tersebut dirancang dengan tepat untuk memaksimalkan pencapaian nilai bersih (net value achievment), yaitu jika semua nilai yang relevan yang di masyarakat diketahui. Model ini terdiri dari beberapa elemen yaitu :

1. Pembuat keputusan dihadapkan dengan suatu masalah tertentu. masalah dapat dipishakan dengan masalah0masalah yang lain atau paling tidak masalah tersebut dapat dipandang bermakna, jika dibandingkan dengan masalahmasalah yang lain.

2. Tujuan-tujuan, nilai-nilai atau sasaran yang mengarahkan pembuat keputusan dijelaskan dan disusun berdasarkan arti pentingnya.

3. Dilakukan berbagai kajian terhadap berbagai alternatif untuk mengatasi masalah.

4. Konsekuensi-konsekuensi (biaya dan keuntungan ) yang timbul dari setiap pemilihan diteliti.

5. Setiap alternatif dan konsekuensi yang menyertainya dapat dibandingkan dengan alternatif-alternatif lain.

6. Melakukan pemilihan ternadap alternatif kebijakan yang paling efisien.

c. Model Kepuasan.

Model kepuasan dikembangkan oleh Simon dan Mach dengan menggunakan pendekatan dimensi perilaku. Penekanannya adalah pada aspek-aspek sosio-psikologis.

d. Model Penambahan (the Incremental Model).

Model ini merupakan kritik terhadap model Rasional Komprehensif. Dikemukakan bahwa kebijakan atau keputusan selalu bersifat serial, fragmentery, dan sebagian besar remedial.

e. Model Pengamatan Campuran.

Model ini merupakan gabungan antara model Rasional Komprehensi dan model Incremental. Model ini lebih merupakan mixedscanning. Model ini merupakan model yang memperhitungkan keputusankeputusan pokok dan inkremental, menetapkan proses-proses pembautan kebijakan pokok dan urusan tinggi yang menetukan petunjuk-petunjuk dasar, proses-proses yang mempersiapkan keputusan-keputusan pokok

f. Model Kualitatif Optimal

Model ini ditawarkan oleh Dror (1971). Adapun substansi dari model ini adalah sebagai berikut :

1. Model ini adalah model kualitatif.

2. Mempunyai komponen-komponen rasional dan ekstra rasioal. 
3. Landasan pemikiran adalah rasional secara ekonomi

4. Mempunyai kaitan dengan metapolicy.

5. Memiliki a built-in feedback.

Border Crossing Agreement antara Indonesia dan Philipina adalah hasil pemikiran murni dari para pengambil keputusan, oleh karenanya dampaknya hal ini tidak dapat "menjawab" persoalan-persoalan nyata yang terjadi di lapangan. Oleh karenanya sangat perlu untuk dilakukan reformulasi terhadap kesepatan ini.

Dalam kaitannya dengan hal ini, maka pendekatannya adalah harus dimulai dari menangkap seluruh fakta riil di lapangan, serta juga mengakomodasi seluruh nilai-nilai yang ada di dalam masyarakat perbatasan kedua negara. Atas dasar ini maka pendekatan Rasioal Komprehensif menjadi relevan untuk menjelaskan persoalan ini. dibutuhkan pemahaman yang rasional untuk mengatur perdagangan lintas batas yang selam ini terjadi. Pengaturan illegal fishing harus mempertimbangkan aspek rasionalitas ekonominya. Regulasi yang ditetapkan haruslah mengedepankan aspek hubungan historis antara dua wilayah ini.

Atas dasar kerangka berpikir di atas, maka proposisi dalam penelitian ini adalah "reformulasi kebijakan pengaturan pelintas batas antara Indonesia - Philipina harus memenuhi aspekaspek Rasionalitas Komprehensif Formulasi Kebijakan".

\section{METODE PENELITIAN}

Desain dari penelitian ini adalah kualitatif. Tujuannya adalah untuk menggambarkan, meringkaskan berbagai kondisi, berbagai situasi, atau berbagai fenomena realitas sosial yang ada, kemudian berupaya untuk menarik realitas ke permukaan sebagai suatu ciri, kharakter, sifat, model, tanda, atau gambaran tentang kondisi, ataupun fenomena tertentu. Format ini fokus pada suatu unit tertentu dari berbagai fenomena. Adapun data yang dipergunakan dalam penelitian ini adalah data primer dan data sekunder. Data primer adalah data yang langsung direkam di lapangan melalui wawancara mendalam dan yang didapat melalui observasi yang dilakukan oleh peneliti sendiri. Sementara itu data sekunder adalah data olahan atau data telah dipublikasikan secara resmi yang didapat dari berita media, dokumentasi dan arsip lembaga terkait lainnya. sementara informan dalam penelitian ini adalah Pedagang lintas batas dari pihak Indonesia (3 orang), Pedagang lintas batas dari pihak Philipina (3 orang). Camat di Desa-desa perbatasan. Masyarakat di sekitar area perdagangan lintas batas (3 orang). Kepala Bidang Pengelolaan Perbatasan Pemerintah provinsi Sulawesi Utara, dan Asisten I pemerintah Kabupaten Kepulauan Talaud.

Penelitian ini menggunakan teknik pengumpulan data wawancara mendalam (in depth-interview). Pada dasarnya wawancara mendalam yang dilakukan dalam penelitian ini merupakan wawancara tidak berstruktur, meskipun disiapkan pula pedoman untuk melakukan wawancara. Kegiatan wawancara dengan para informan dilakukan di tempat yang berbeda-beda, sesuai dengan kesepakatan y yang dibuat. Peneliti mendatangi satu per satu para informan di tempat yang berbeda-beda. Selanjutnya Teknik pengujian keabsahan data yang dilakukan dalam penelitian ini adalah menggunakan teknik triangulasi. Data dan temuan-temuan baru yang diperoleh, diuji dengan melakukan cross check data, kemudian dianalisa dengan cara mengkombinasikan interpretasi peneliti dengan teori rujukan, serta teori lainnya yang berkaitan dengan temuan-temuan dalam penelitian.

\section{HASIL DAN PEMBAHASAN}

Penelitian lapangan dilakukan di kantor Kabupaten Kepulauan Talaud, desa Makatara Kecamatan Beo Utara, Desa Bulude kecamatan Essang dan Desa Bowombaru kecamatan Melonguane Timur. Penelitian di kantor Bupati adalah menggali data dari pejabat Asisten I yang salah satu bidang yang menjadi tanggung 
jawabnya adalah soal pelintas batas. Tiga desa di kabupaten Kepulauan Talaud ini adalah desa-desa yang terdapat kelompok atau keluarga-keluarga yang merupakan pelintas batas. ada tiga kharakteristik pelintas batas yang ditemukan yaitu

1. Pertama adalah pelintas batas warga negara Indonesia (penduduk kepulauan Talaud dan atau Sangihe) yang melakukan kegiatan lintas batas, murni untuk tujuan perdagangan. Perdagangan yang umum dilakukan adalah bidang perikanan,dan kemudian adalah bahan-bahan kebutuhan primer seperti sabun cuci, sabun mandi, dan rokok sebagai produk Indonesia yang paling disukai oleh masyarakat Philipina Selatan. Hasil tangkapan ikan dari wilayah laut Kepulauan Talaud dibeli dengan harga tinggi dan mendapatkan perlakuan yang jauh lebih baik dibandingkan jika dijual di pelabuhan pelelangan ikan kota Bitung (hasil wawancara dengan komunitas pelintas batas di desa Makatara, dan desa Bulude).

2. Kedua adalah pelintas batas orang kepulauan Talaud dan dari kepulauan Sangihe yang memiliki hubungan kekerabatan yang erat dengan saudarasaudara mereka yang sebagian besar sudah lahir dan menetap di philipina Selatan. Tujuan utama dari perjalanan lintasnya adalah untuk kunjungan kekeluargaan sekaligus juga untuk berdagang. Umumnya berangkat dengan membawa hasil tangkapan ikan, kem

3. Kategori ke tiga adalah warga Philipina Selatan, etnik asli phillipina Selatan yang masuk ke wilayah kabupaten kepulauan Talaud untuk tujuan perdagangan.

4. Kategori ke empat adalah etnik Sangihe dan etnik Talaud yang lahir atau sudah bertahun-tahun tinggal di Philipina Selatan dan sudah menjadi warga negara, yang melakukan pelayaran lintas batas untuk tujuan perdagangan dan kunjungan kekeluargaan.

5. Kategori ke lima adalah etnik Sangihe dan etnik Talaud yang lahir atau sudah bertahun-tahun tinggal di Philipina Selatan, tetapi memilih untuk tidak menjadi warga negara Phillipina. Tujuan perjalanan lintas batasnya adalah untuk kunjungan kekeluargaan dan sedikit untuk tujuan perdagangan.

Dari hasil wawancara yang dilakukan diperoleh data bahwa, pada dasarnya hubungan lintas batas ini dapat memberikan keuntungan yang signifikan bagi warga perbatasan. Namun demikian hal tidak tercapai oleh karena terkendala tidak adanya regulasi maupun perjanjian perbatasan antara Indonesia dan Philipina. Ikan dari perairan kepulauan Talaud merupakan komoditas dengan harga jual tinggi di Philipina Selatan, sementara rokok Indonesia sangat disukai oleh masyarakat Phillipina Selatan. dari hasil penjualan ikan di Phillipina Selatan, orang-orang perbatasan membeli barang-barang sekunder seperti berbagai keperluan rumah tangga. Di desa Makatara misalnya, ditemukan material untuk pembuatan perahu yang merupakan produk Phillipina. Ini dibeli oleh komunitas pelintas batas, kemudian dibawa ke wilayah Talaud.

Namun demikian persoalannya adalah perdagangan seperti ini, menjadi sebuah perdagangan yang sifatnya ilegal dan tidak memberikan keuntungan bagi daerah. Dari penelitian ini juga ditemukan bahwa sentra perdagangan ilegal dalam jumlah yang besar adalah berada di Pulau Marore yang masuk dalam wilayah kabupaten kepulauan Sangihe. Dari sini kemudian barang-barang yang masuk terdistribusi secara ilegal ke ibukota kabupaten Kepulauan Sangihe (Tahuna) dan kabupaten Kepulauan Talaud (Melonguane). Di dua pusat kota ini barang-barang Phillipine ada yang jual secara terang-terangan dan ada yang dijual secara sembunyi-sembunyi.

Pada dasarnya kondisi ini memperlihatkan bahwa perjanjian perbatasan antara Indonesia - 
Phillipine yang berbunyi sebagai Border Crossing Agreement, sudah sangat urgen untuk segera direvisi. Oleh karena ternyata hubungan lintas batas antara masyarakat dua negara ini, sangat berpotensi untuk mengembangkan perekonomian masyarakat wilayah perbatasan.

\section{PENUTUP}

Kesimpulan

Dari hasil penelitian yang telah selesai dilakukan maka diperoleh kesimpulan sebagai berikut :

1. Border Crossing Agreement antara Indonesia - Phillipina sudah tidak relevan dan tidak dapat mengakomodir berbagai "bentuk" kegiatan pelintas batas antara masyarakat dua negara.

2. Kegiatan lintas batas antar dua negara, berpotensi untuk memberikan keuntungan ekonomi yang signifikan bagi masyarakat perbatasan di wilayah kabupaten Kepulauan Talaud dan juga termasuk kabupaten kepulauan Sangihe.

3. Border Crossing Agreement belum juga direvisi oleh karena kurangnya perhatian pemerintah antar dua negara, terutama sekali dari pihak Indonesia.

Saran

Adapun saran dari penelitian ini adalah sebagai berikut di bawah ini :

1. Pemerintah Indonesia harus segera melakukan pendataan yang matang, tentang berbagai bentuk kegiatan yang dilakukan oleh para pelintas batas kedua negara. Dari hasil pendataan ini kemudian harus dilakukan analisa potensi ekonomi yang dapat dihasilkan dari kegiatan ini. Selanjutnya pemerintah Indonesia harus berinsiatif mengundang pemerintah Phillipina untuk secara bersama-sama menbahas ulang Border Crossing Agreement antara kedua negara, dan kemudian selanjutnya membuat kesepakatan-kesepakatan yang sifatnya lebih teknis operasional, yang dapat dilakukan di tingkat Kementerian.

2. Pemerintah Indonesia harus segera mengeluarkan regulasi pedagangan lintas batas yang disepakati oleh kedua negara. Tetapi hal ini secara teknis juga harus didukung oleh Kementerian Kelautan dan Perikanan, serta Kementerian Pertahanan dan Keamanan. Karena Patroli perbatasan menjadi "masalah" tersendiri bagi para nelayan dan pelintas batas.

3. Revisi Border Crossing Agreement harus segera dilakukan, dan diikuti dengan pengaturan-pengaturan yang sifatnya lebih teknis.

\section{REFERENSI}

[1] Dunn, William N, Pengantar Analisis Kebijakan Publik Edisi Kedua. Gadjah Mada Univesity Press: Yogyakarta, 2003

[2] Islamy, M. Irfan, Prinsip-Prinsip Perumusan Kebijakan Negara., Jakarta : Bumi Aksara, 2002

[3] Mamentu Michael, dan Joyce Jacinta Rares., Evaluasi Dampak Sosial Ekonomi Dan Politik Border Crossing Agreement Pada Masyarakat Perbatasan Kabupaten Kepulauan Talaud Provinsi Sulawesi Utara (Studi Dalam Rangka Rekomendasi Revisi Kebijakan Pengaturan Pelintas Batas Indonesia - Philipina)., Manado : Jurnal LPPM Unsrat, 2017

[4] -------,Pengembangan Program Pemberdayaan Nelayan Tangkap Di Kabupaten Kepulauan Talaud., Manado : Jurnal LPPM Unsrat, 2016

[5] Mamuaja, Bertha., Pelaksanaan Kebijakan Border Crossing Agreement oleh Kantor Imigrasi Kabupaten Kepulauan Sangihe (penelitian)., Manado : FISIP Unsrat, 2017

[6] Nugroho, D. Riant, Kebijakan Publik Untuk NegaraNegara Berkembang. PT Alex Media Komputindo: Jakarta, 2008

[7] Winarno Budi., Kebijakan Publik Era Globalisasi., Yogyakarta : CAPS, 2016 